\title{
Egas Moniz: geniusz, pechowiec czy pomyłka Komitetu Noblowskiego?
}

\section{Egas Moniz: a genius, unlucky looser or a Nobel Committee error?}

\author{
Piotr Lass ${ }^{1,2}$, Jarosław Stawek ${ }^{3,4}$, Emilia Sitek,4 \\ IZakład Medycyny Nuklearnej, Gdański Uniwersytet Medyczny \\ 2Zakład Spektroskopii Molekularnej, Instyłut Fizyki Doświadczalnej, Uniwersytet Gdański \\ 3 Zakład Pielęgniarstwa Neurologiczno-Psychiatrycznego, Gdański Uniwersyytet Medyczny \\ 40ddział Neurologii, Szpital Specialistyczny św. Woiciecha w Gdańsku
}

Neurologia i Neurochirurgia Polska 2012; 46, 1: 96-103

DOI: 10.5114/ninp.2012.27452

\section{Streszczenie}

Portugalski neurolog António Egas Moniz jest jedną z najbardziej intrygujących postaci w historii medycyny. O ile wynalezienie w 1927 r. angiografii jest jego trwałą zasługą, o tyle wynaleziona przez niego w 1935 r. lobotomia została czarną legendą psychiatrii, choć sporadycznie wykonuje się ją i dziś. Pojawiły się nawet postulaty odebrania Monizowi Nagrody Nobla przyznanej w 1949 r. za wynalezienie lobotomii. Moniz rzeczywiście ponownie opisał lobotomię, pierwotnie wprowadzoną w 1888 r. przez szwajcarskiego psychiatrę Gottlieba Burckhardta, a następnie zapomnianą. Rozpowszechnienia jednak tej metody, w tym jej nadużyć, dokonali głównie amerykańscy neurolodzy Walter Freeman i James Watts. Poza nauką Moniz był wyjątkowo barwną postacią, m.in. zasłużonym politykiem, ministrem spraw zagranicznych Portugalii i przewodniczącym jej delegacji na pokojowej konferencji w Wersalu, w 1951 r. proponowano mu nawet objęcie stanowiska prezydenta Portugalii. Był również wszechstronnie uzdolnionym humanistą i pisarzem, nawet ekspertem gier hazardowych. Osoba Moniza wymyka się czarno-białym ocenom, zdecydowanie zasługując na reewaluację z dzisiejszej perspektywy historycznej.

Słowa kluczowe: António Egas Moniz, angiografia, lobotomia.

\begin{abstract}
Portuguese neurologist António Egas Moniz is one of the most intriguing figures in the history of medicine. While an invention of angiography in 1927 is his acknowledged merit, lobotomy, invented in 1935 became a black legend of psychiatry, although sporadically it is performed also today. There are even postulates to withdraw the Nobel Prize, which Moniz received in 1949 for inventing the lobotomy. Moniz in fact re-invented lobotomy, primarily introduced in 1888 by a Swiss psychiatrist Gottlieb Burckhardt and later forgotten. Its popularisation, including its abuses was chiefly done by American neurologists Walter Freeman and James Watts. Aside the science, Moniz was an exceptionally colourful person, a merited politician, Portuguese minister of foreign affairs, the head of its delegation at Versailles in 1918, in 1951 he was even proposed a position of a President of Portugal. He was a versatile humanist and a writer, even a gambling expert. His person is hard for black and white evaluation, definitely deserving a re-evaluation from today's historical perspective.
\end{abstract}

Key words: António Egas Moniz, angiography, lobotomy.

Adres do korespondencji: prof. Piotr Lass, Zakład Medycyny Nuklearnej, Gdański Uniwersytet Medyczny, ul. Dębinki 7, 80-211 Gdańsk, tel./faks +48583492200, e-mail: plass@gumed.edu.pl Pracę otrzymano: 30.08.2011; przyięto do druku: 24.01.2012 
Nagroda Nobla w zakresie medycyny i fizjologii, w odróżnieniu od jej pokojowego odpowiednika, zwykle nie budzi większych kontrowersji. Postulaty odebrania nagrody w dziedzinie medycyny są rzadkie, acz pojawiły się na przykład w odniesieniu do Juliusa Wagner-Jauregga (1857-1940), twórcy kontrowersyjnej metody leczenia powikłań kiły wstrzyknięciem zarodźców malarii, lub Johannesa Fibigera (1867-1928), odkrywcy rzekomo rakotwórczego nicienia Spiroptera carcinoma.

Wśród „wątpliwych” laureatów tej nagrody prawdopodobnie najciekawszą postacią jest jednak António Egas Moniz (1874-1955), portugalski neurolog, uhonorowany w 1949 r. Nagrodą Nobla za „odkrycie wartości leczenia leukotomią w niektórych psychozach” [1]. Moniz był postacią barwną i intrygującą. Oprócz opracowania metody leukotomii, wcześniej zasłynął wynalezieniem angiografii jako metody radiologicznej. Jako polityk był wieloletnim deputowanym do parlamentu portugalskiego, ministrem spraw zagranicznych Portugalii i przewodniczącym delegacji portugalskiej na konferencję pokojową w Wersalu. Był również znawcą gier hazardowych, poetą, krytykiem literackim, a nawet kompozytorem. Ostatnie 16 lat życia częściowo spędził na wózku inwalidzkim, postrzelony przez niezadowolonego pacjenta.

\section{Podstawowe dane biograficzne}

António Caetano de Abreu Freire Egas Moniz urodził się 29 listopada 1874 r. w Avançy k. Aveiro, tam również 13 grudnia 1955 r. zmarł. Człon „Egas Moniz” został dodany przez jego ojca chrzestnego, wuja i katolickiego opata Caetano de Abreu Sá Freire na pamiątkę bohatera portugalskich walk z Maurami w XII w. Rodzina Freire zaliczała się do grona portugalskiej arystokracji, lecz w końcu XIX w. była już nieco zubożała. W wieku 17 lat Moniz wstąpił na Uniwersytet w Coimbrze, gdzie pierwotnie uzyskał stopnień magistra matematyki i nauk ścisłych, a następnie ukończył w 1899 r. studia medyczne. Jako asystent Uniwersytetu w Coimbrze doskonalił się w neurologii w Bordeaux i Paryżu, gdzie jego mistrzami byli znani francuscy neurolodzy Józef Babiński (1857-1932), Joseph Jules Dejerine (18491917), Pierre Marie (1853-1940) i Jean Athanase Sicard (1872-1929). Zwłaszcza ten pierwszy był mentorem Moniza, a później jego gorącym zwolennikiem. Notabene Moniz dość szybko zasłynął również jako bon vivant, smakosz i karciarz, stoczył też nielegalny skądinąd w tym czasie we Francji pojedynek [2,3].
W 1911 r., w wieku 37 lat, obją jako profesor katedrę neurologii na nowo utworzonym Uniwersytecie w Lizbonie, gdzie pracował do emerytury w 1944 r., a praktycznie do końca życia. Na wiele lat pochłonęła go polityka i dopiero po jej opuszczeniu w 1920 r. dokonał najważniejszych wynalazków: angiografii w wieku 53 lat, a lobotomii w wieku 61 lat (dość rzadkie w historii nauki). W 1939 r., w wieku 65 lat, został częściowo sparaliżowany lewostronnie na skutek wielokrotnego postrzelenia przez pacjenta chorego na schizofrenię. Motywy postrzelenia są niejasne, najczęściej podawaną wersją jest niezadowolenie chorego z wysokości dawki leku przepisanego przez Moniza.

\section{Arteriografia mózgowa}

Moniz jest wynalazcą arteriografii mózgowej i pierwszego udanego tego typu badania wykonanego 28 czerwca 1927 r. [4]. Droga do udanego angiogramu była wyboista. Moniz rozpoczął badania na psach i zwłokach, dość szybko jednak - być może zbyt szybko - rozpoczął wykonywanie angiografii u ludzi z użyciem bromku strontu w stężeniu $70 \%$ jako środka kontrastującego. $\mathrm{U}$ pięciu pierwszych chorych pojawiły się silne objawy uboczne, z wyjątkiem pierwszego uzyskane obrazy były niediagnostyczne, a szósty badany zmarł. Moniz zmniejszył wówczas stężenie bromku strontu w kontraście do 25\%, wówczas jednak jakość obrazu naczyń była niewystarczająca. Dopiero gdy zastosował jodek sodu jako środek kontrastowy, u dziewiątego badanego chorego uzyskano w pełni diagnostyczny obraz patologicznych naczyń guza przysadki [3,5]. Moniza nie zadowalały statyczne obrazy angiograficzne i wspólnie z radiologiem Pereirą Caldasem opracowali sposób filmowania przepływu krwi za pomocą zbudowanej przez nich „karuzeli”, która pozwalała uzyskać 6 radiogramów w ciągu sekundy. Moniz i współpracownicy opublikowali ok. 200 prac poświęconych prawidłowej i patologicznej angiografii mózgowej, również innych narządów.

Moniz uczestniczył w opracowaniu pierwszego kontrastu angiograficznego, Thorotrastu, który stosowano przez dwie dekady [2]. Thorotrast został jednak wycofany z użycia na przełomie lat 40. i 50., gdy okazało się, że promieniowanie alfa emitowane przez wchodzący w skład kontrastu dwutlenku toru radioizotop toru ${ }^{232} \mathrm{Th}$ było silnie rakotwórcze. Cząsteczki Thorotrastu ulegały znacznemu wychwytowi w wątrobie i śledzionie, wtórnie wywołując ich nowotwory, a jego regionalna retencja mózgowa indukowała guzy tego narządu. 


\section{Leukotomia/lobotomia}

Lobotomia zdecydowanie nie ma dobrej prasy. $\mathrm{Na}$ gruncie kultury masowej pogrążył ją film „Lot nad kukułczym gniazdem" (1975) Miloša Formana z Jackiem Nicholsonem w roli głównej, wokół lobotomii obraca się również fabuła filmu „Wyspa tajemnic” (Shutter Island) Martina Scorsese ze znakomitą obsadą aktorską Leonarda DiCaprio, Maxa von Sydowa i Bena Kingsleya (2010)

$\mathrm{Na}$ gruncie medycznym lobotomię tym bardziej odsądzono od czci i wiary. Psychochirurgia oczywiście weszła na trwałe do armamentarium nowoczesnej psychiatrii [6]. Stereotaktyczna cingulotomia, kapsulotomia, traktotomia jądra ogoniastego i leukotomia limbiczna mogą zdziałać wiele, jeżeli stosowane są rozważnie i pod kontrolą, przykładem czego jest Komitet Cingulotomii Massachusetts General Hospital w USA. Obecnie głównymi kierunkami psychochirurgii jest głęboka stymulacja mózgu, terapia genowa i leczenie komórkami macierzystymi [7]. Wynalezienie głębokiej stymulacji mózgowej nie byłoby możliwe, gdyby nie wcześniejsze zabiegi ablacyjne, które utorowały drogę aktualnie stosowanym technikom, które ablacji nie wymagają [8]. Obecnie poszukuje się odpowiednich miejsc uszkodzenia (np. poprzez stymulację elektryczną), które skutkowałyby poprawą w zakresie depresji czy innych zaburzeń psychiatrycznych, na wzór sukcesów uzyskanych w leczeniu choroby Parkinsona za pomocą stymulacji jądra niskowzgórzowego czy częściowych sukcesów leczenia zespołu de la Tourette’a za pomocą stymulacji różnych struktur (np. wybrane jądra wzgórza, część limbiczna gałki bladej czy jądro półleżące). Leczenie chirurgiczne jest jednak dziś zarezerwowane jedynie dla chorych, u których farmakoterapia nie przynosi zdecydowanej poprawy. Wynalezienie chloropromazyny nie wyparło natychmiast lobotomii, zajęło to jeszcze kilkanaście lat. Lobotomia doczekała się jednak wczesnej krytyki już w latach 40. XX w. Szwedzki psychiatra Snorre Wohlfart już w 1947 r. pisał: „lobotomia jest zbyt niedoskonała, by upoważnić nas do ogólnej ofensywy przeciwko chorobom psychicznym” i że: „psychochirurgia dotąd nie dała podstaw do ustanowienia dokładnych wskazań i przeciwwskazań, dlatego metoda ta - niestety - powinna być uważana za niedopracowaną i ryzykowną" [9]. W 1948 r., na rok przed przyznaniem Monizowi Nagrody Nobla, twórca cybernetyki, Norbert Wiener, bezlitośnie i złośliwie skrytykował metode, piszac: „Lobotomia przedczołowa ostatnio stała się pewną modą, prawdopodobnie nie bez związku $\mathrm{z}$ fak- tem, że ułatwia kontrolę chorych. Pozwolę sobie na uwagę, że uśmiercenie chorych jeszcze bardziej ułatwiłoby taką kontrolę" [10].

Pierwszym krajem, w którym zakazano lobotomii, niespodziewanie był - już w 1950 r. - Związek Radziecki [11]. W rozporządzeniu Ministerstwa Zdrowia ZSRR stwierdzono, że „metoda ta jest przeciwna zasadom humanizmu” i że „zmienia chorego psychicznie w idiotę". Podejście zdroworozsądkowe, acz zadziwiające, jak na kraj znany z nadużyć w psychiatrii. Istnieją opinie, że zakazu tego dokonano z powodów ideologicznych [12]. Jest to skądinąd możliwe, gdyż data zakazu pokrywa się ze szczytem kampanii przeciwko osiągnięciom nauki krajów zachodnich. W 1956 r. lobotomii zakazano w Brazylii [13]. Lobotomia prawie zanikła na początku lat 70. XX w., aczkolwiek sporadycznie wykonuje się ją również w naszym stuleciu.

Moniz w zasadzie nie był ani pomysłodawcą lobotomii przedczołowej, ani nie on ją rozpowszechnił. Nawet nigdy nie wykonał lobotomii osobiście. $Z$ powodu zaawansowanej dny moczanowej, na którą cierpiał od 28. roku życia, i zmian zwyrodnieniowych stawów również dłoni, pozostawiał wykonywanie zabiegów neurochirurgowi Pedro de Almeidzie Limie (1903-1983).

Moniz nie był pionierem lobotomii $[14,15]$. Zabieg ten po raz pierwszy wykonał w 1888 r. szwajcarski psychiatra Gottlieb Burckhardt (1836-1907). Burckhardta prawdopodobnie inspirowały wyniki doświadczeń Friedricha Goltza (1834-1902), który zauważył, że psy po usunięciu płatów skroniowych mózgu były spokojniejsze. Burckhardt w 1888 r. wykonał sześć lobotomii i pozostał niezauważony mimo prezentacji wyników na kilku kongresach naukowych. Nie miał szans wobec takich ówczesnych sław neurologicznych, jak Kraepelin i Seppili [15]. W 1900 r. kilka lobotomii wykonał estoński chirurg Ludwik Pussepp, chirurgicznie lub chemicznie uszkadzając połączenia płatów czołowych, bez specjalnych efektów terapeutycznych. Jego praca również pozostała niezauważona.

W 1935 r. na jednym z seminariów Second International Congress of Neurology w Londynie Moniz i Lima byli świadkami prezentacji przez Carlyle’a Jacobsena i Johna Farquahara Fultona, neurofizjologów doświadczalnych z Uniwersytetu Yale, dwóch szympansów, Becky i Lucy, po usunięciu płatów czołowych mózgu. Odkrycie Jacobsena i Fultona było w zasadzie przypadkowe. Prowadzili oni badania nad pamięcią i procesami przyswajania wiedzy u szympansów. Szympansica Becky gwałtownymi wybuchami złości utrudniała badania i była wręcz niebezpieczna dla eksperymentatorów. 
Jacobsen usunął Becky lewą część płata czołowego, co nie zmieniło jej zachowania. Następnie u tej samej szympansicy usunięto również płat prawy czołowy. Becky stała się zwierzęciem posłusznym, uległym i współpracującym. Monizowi zaimponował kamienny spokój zwierząt doświadczalnych po operacji. Twierdził później, że sam myślał o podobnej metodzie już przed konferencją, ale nie ma na to dowodów. Założenia teoretyczne Moniza były dość proste. Uważał, że przyczyną zaburzeń psychicznych są nawracające bodźce krązące między płatami czołowymi a wzgórzem, zatem przecięcie tych połączeń usunie przyczynę choroby. Myśl o lobotomii jako metodzie terapeutycznej owładnęła Monizem całkowicie. Dwunastego listopada 1935 r. przeprowadził pierwszą leukotomię - jak to wówczas określił - u chorej ze schizofrenią paranoidalną, wstrzykując, przez otwory wywiercone w czaszce, w płaty czołowe mózgu etanol. Od siódmego zabiegu Moniz stosował obmyślony przez siebie aparat, przecinający drutem szlaki istoty białej w płatach czołowych. Pierwszy opis metody Moniz opublikował już w 1936 r., przedstawiając wyniki 20 zabiegów: 13 u chorych z chorobą afektywną dwubiegunową i 7 ze schizofrenią [16]. Wyniki zabiegów Moniz uznał za bardzo obiecujące, mimo że okres obserwacji wynosił tylko kilka lub kilkanaście dni, a sposób jej przeprowadzenia był bardzo subiektywny. Przykładowo, u pierwszej operowanej chorej Moniz podkreślił cofnięcie się rozhamowania i urojeń, marginalnie tylko zaznaczając pojawienie się objawów apatii i zaburzeń funkcji poznawczych.

Nie sposób nie odnieść się do tego zagadnienia bez przypomnienia danych neurofizjologicznych według obecnej wiedzy. Płaty czołowe odgrywają kluczową rolę w regulacji funkcjonowania poznawczego i emocjonalnego człowieka. Aktualnie opisuje się trzy warianty zespołu czołowego: podstawno-nadoczodołowy (oczodołowy), przyśrodkowy i grzbietowo-boczny. W pierwszym wariancie dominuje rozhamowanie, $\mathrm{w}$ drugim zaburzenia napędu, w trzecim zaś - zaburzenia planowania i myślenia abstrakcyjnego, sztywność poznawcza oraz zaburzenia pamięci operacyjnej. Podsumowując wpływ lobotomii na funkcjonowanie psychiczne pacjenta w świetle aktualnej klasyfikacji zespołów czołowych, można zaryzykować stwierdzenie, że ceną zmniejszenia objawów pierwszego wariantu zespołu czołowego (m.in. zaburzeń kontroli zachowania) było często wywołanie objawów wariantu przyśrodkowego (głównie apatii i spadku napędu psychoruchowego) i wariantu grzbietowo-bocznego (zaburzeń funkcji wykonawczych, np. planowania).
Powracając do postaci Moniza, konieczne wydaje się odniesienie do kontekstu historycznego, czyli stanu psychiatrii w tym okresie. Era leków neuroleptycznych miała nadejść dopiero po 1953 r. W czasach Moniza szpitale psychiatryczne były zatłoczone, a wskaźniki śmiertelności chorych przerażające, przede wszystkim na skutek gruźlicy. Dlatego chętnie zwracano się ku jakimkolwiek obiecującym metodom terapeutycznym, nie tylko lobotomii, lecz również terapii głębokiego snu (1920), wstrząsów insulinowych (1933), wstrzą̧ów kardiazolowych (1934) lub wprowadzonych w 1938 r. elektrowstrząów [17].

Technikę lobotomii w świecie psychiatrycznym rozpowszechnił nie Moniz, ale Walter Jackson Freeman (1895-1972), profesor George Washington University w Waszyngtonie [18]. Osobiście lub wspólnie z długoletnim partnerem Jamesem Winstonem Wattsem wykonał nie mniej niż 3400 lobotomii w 23 stanach USA, aczkolwiek nie posiadał formalnych uprawnień chirurga. W rekordowych dwóch tygodniach 1952 r. wykonał 228 lobotomii metodą przezoczodołową. Freeman zmodyfikował technikę leukotomii, przemianował ją na 'lobotomię', wykonując ją często ambulatoryjnie z dojścia oczodołowego, podróżując po kraju specjalnym wozem o nazwie „lobotomobil”. Popularność lobotomii rosła. Metodę rozsławiła wspólnie wydana w 1942 r. monografia [19]. Freeman do przeprowadzania lobotomii przezoczodołowej opracował specjalny instrument nazwany „orbitoklastem” lub „leukotomem”, ze względu na wizualne podobieństwo zwany potocznie „szpikulcem do lodu". Czas wykonywania lobotomii został skrócony do 10 min, zdarzało się wykonywanie lobotomii w pokojach hotelowych. W samym 1949 r. w USA wykonano ich ok. 5000. Schyłek kariery Freemana i lobotomii rozpoczął się po mniej więcej dwóch dekadach. Początkowe niepowodzenia, takie jak dramatyczne zmiany osobowości po lobotomii u siostry Johna Kennedy'ego, Rosemary, przeszły prawie niezauważone. W $1950 \mathrm{r}$. z Freemanem rozstał się James Watts, motywując to nadużywaniem lobotomii i jej okaleczającym charakterem. Wprowadzenie do użytku chlorpromazyny w 1953 r. znacznie ograniczyło wskazania do psychochirurgii. Symbolicznym końcem kariery Freemana była jego ostatnia lobotomia (wykonana po raz trzeci) w lutym 1967 r. u Helen Mortensen, która w wyniku następowego krwawienia zmarła. Freemanowi zabroniono wówczas wykonywania lobotomii. Przeszedł na emeryturę w 1968 r., zajmując się badaniami odległych skutków lobotomii. Zmarł w wyniku choroby nowotworowej 31 maja 1972 r. w wieku 76 lat. Jego imię nie 
cieszy się w USA najlepszą sławą, mimo niewątpliwych zasług, np. istotnego wkładu w psychiatrię biologiczną i utworzenia American Board of Psychiatry and Neurology.

Moniz do końca życia pozostał zwolennikiem lobotomii [20] i Freemana. W 1948 r. nominowal go do członkostwa w Lizbońskiej Akademii Nauk (Academia dos Ciencias de Lisboa). Nic dziwnego. W 1948 r. niewiele wskazywało na całkowitą porażkę lobotomii.

\section{Nagroda Nobla}

Egas Moniz do Nagrody Nobla nominowany był pięciokrotnie, w latach 1928, 1933, 1937, 1944 i 1949. Pierwsze dwie nominacje miały związek $\mathrm{z}$ wynalezieniem arteriografii. Nominacja z 1928 r. została złożona prawie natychmiast po demonstracji arteriografii w Szpitalu Neckera w Paryżu, ponieważ w tym czasie przestrzegano jeszcze reguły ustalonej przez Alfreda Nobla, że nagroda powinna być przyznawana za prace opublikowane w roku poprzedzającym jej wręczenie. Pierwszą i drugą nominację złożyło dwóch kolegów z Uniwersytetu w Lizbonie. Komitet Noblowski uznał jednak dwukrotnie, że wynalezienie angiografii nie stanowi wystarczającego powodu do wyróżnienia [21]. Personalnie w obu przypadkach za odmową stał przewodniczący Komitetu Noblowskiego Hans Christian Jacobaeus z Karolinska Institutet w Solna (Szwecja), prawdopodobnie inspirowany przez Waltera Dandy'ego, amerykańskiego pioniera neurochirurgii, wynalazcy wentrykulografii i pneumoencefalografii [22]. Motywy odmowy nie są do końca jasne, być może sądzili, że udział w wynalezieniu angiografii nie jest ograniczony do osoby Moniza lub kwestionowali jego pierwszeństwo [23].

Pierwszej nominacji Moniza do Nagrody Nobla za wynalezienie lobotomii sprzeciwił się w 1937 r. wybitny szwedzki neurochirurg, Herbert Axel Olivecrona (1891-1980), kierownik Kliniki Neurochirurgii w Karolinska Institutet. Nominacji w 1944 r. sprzeciwił się znany szwedzki neurochirurg z uniwersytetu w Lund, Erik Essen-Moller, argumentując, że „zabieg ten jest i będzie okaleczający. Pozostaje niejasne, czy efekty pozytywne przeważą nad negatywnymi" [24].

Po raz trzeci do Nagrody Nobla Moniza w 1949 r. za wynalezienie lobotomii nominowało trzech naukowców z Lizbony, dwóch z Brazylii, jeden z Danii. Ponownie recenzentem był Herbert Olivecrona, który tym razem zmienił zdanie. Olivecrona podkreślał niską śmiertelność oraz niski odsetek efektów ubocznych, w konkluzji oceniając lobotomię jako istotny postęp w terapii. Zdanie Olivecrony przeważyło, Moniz otrzymał tę nagrodę.

Nagroda dzielona była ze szwajcarskim neurofizjologiem Walterem Hessem. Moniz był pierwszym i dotąd ostatnim portugalskim naukowcem, który otrzymał tę nagrodę. Jeden z największych oponentów postaci Moniza, Elliot Valenstein, utrzymuje, że wyróżnienie było możliwe wskutek niezwykle małej liczby nominacji w roku poprzedzającym [21].

\section{Postulaty odebrania Monizowi Nagrody Nobla}

Odebranie nadanej Nagrody Nobla nie jest możliwe. Zastrzega to statut Fundacji Noblowskiej: no appeals may be made against the decision of a prize-awarding body with regard to the award of a prize. Kontrowersje wokół Nagrody Nobla oprócz wspomnianych we wstępie Wagner-Jauregga i Fibigera dotyczyły również Aleksandra Fleminga (nagroda w 1945 r.), Karla von Frischa (1973), Davida Baltimore'a (1975) i Haralda zur Hausena (2008). Postulatu takiego nigdy jednak nie sformułowano tak expressis verbis, jak w przypadku Moniza.

Najbardziej znaną postacią tej kampanii jest Christine Johnson, amerykańska bibliotekarka medyczna z Levittown w stanie Nowy Jork, której babka, Beulah Jones, została poddana lobotomii w 1954 r. i spędziła resztę życia w domu opieki. Johnson zadając pytanie: „Jak ktokolwiek może zaufać Komitetowi Noblowskie$\mathrm{mu}$, jeżeli nie chcą się przyznać do tak okropnego blędu?" (How can anyone trust the Nobel Committee, when they won't admit to such a terrible mistake?), rozpoczęła kampanię na rzecz pośmiertnego odebrania Monizowi Nagrody Nobla, w latach 2004-2008 prowadząc stronę internetową http://www.psychosurgery.org poświęconą temu zagadnieniu.

Komitet Noblowski zareagował opublikowanym w 1998 r. kontrraportem Bengta Janssona, profesora psychiatrii w Karolinska Institutet, członka Komitetu Noblowskiego. Jansson argumentuje, że w czasach Moniza nie istniała efektywna alternatywa dla lobotomii, ponieważ chloropromazyna została wprowadzona do użytku dopiero po 1952 r., więc z tego względu nie powinno się potępiać leczenia stosowanego, przynajmniej w tej skali, w latach czterdziestych. Raport Janssona do dziś jest widoczny na oficjalnej stronie Komitetu Noblowskiego, Nobelprize.org. Wydaje się, że dyskusja na ten temat jest zamknięta. 


\section{Inne wyróżnienia}

Moniz był odznaczony portugalskim Krzyżem Zasługi Gran-Cruz da Instrução e Benemerência, Wielkim Krzyżem Izabeli Katolickiej, Krzyżem Oficerskim Korony Włoch i komandorią francuskiej Legii Honorowej. Był doktorem honoris causa uniwersytetów w Bordeaux i Lyonie, honorowym członkiem Royal Society of Medicine w Londynie, Académie Nationale de Médecine w Rio de Janeiro oraz American Society of Neurology.

\section{Pozostały dorobek Moniza}

Niedocenioną stroną dorobku Moniza pozostaje jego pionierski wkład w badania nad zwężeniem tętnic mózgowych, zwłaszcza tętnicy szyjnej wewnętrznej oraz jej ocenę angiograficzną. Pierwszy opisał w 1937 r. angiograficzne cechy całkowitego zamknięcia tętnicy szyjnej wewnętrznej [25], a przejście tętnicy szyjnej wewnętrznej przez kość skroniową bywa określane jako „syfon Moniza”. Moniz i wsp. pierwsi wykonali w $1931 \mathrm{r}$. angiografię tętnic płucnych [26]. Najpopularniejszą książką Moniza pozostaje pierwszy w Portugalii podręcznik seksuologii, wydany w $1901 \mathrm{r}$. i wznowiony do 1933 r. 19-krotnie. Jak na bardzo purytańską wówczas Portugalię było to dzieło dość pionierskie [27].

\section{Moniz jako polityk}

Działalność polityczna Moniza trwała od 1903 r. do 1920 r., gdy ponownie zwrócił się ku medycynie. Bezpośrednią przyczyną decyzji odejścia od polityki miał być pojedynek z politycznym oponentem. Kariera polityczna Moniza była długa i interesująca. W 1903 r. założył Partię Republikańsko-Centrową (Partido Republicano Centrista), w 1917 r. został ambasadorem Republiki Portugalii w Madrycie. Były to dla Portugalii burzliwe czasy. W 1910 r. obalono monarchię. W 1916 r. Portugalia przystąpiła do I wojny światowej po stronie Ententy, stąd obecność Moniza jako delegata Portugalii na konferencji pokojowej w Wersalu. Politycznie uchodził za demokratę walczącego z monarchią portugalską [28], aczkolwiek premier Sidonio Pais, dla którego pracował, rządził Portugalią dość autorytarnie. Aktywność polityczną Moniz kilkakrotnie przypłacił krótkim uwięzieniem, ostatni raz w 1916 r. Dwukrotnie był więziony jako student protestujący przeciwko monarchicznej formie rządów. Jako dziekan wydziału lekarskiego Uniwersytetu w Lizbonie został aresztowany za sprzeciwienie się wejściu policji na teren uniwersytetu w celu spacyfikowania studenckiego protestu.

W 1918 r. został portugalskim ministrem spraw zagranicznych i w tej roli był przewodniczącym delegacji portugalskiej na konferencję pokojową w Wersalu. Moniz w Wersalu nie uzyskał dla Portugalii zbyt wiele - odstąpienie ok. $1000 \mathrm{~km}^{2}$ z portem Kionga na pograniczu Mozambiku i niemieckiej wówczas Tanganiki. W 1951 r. mimo nieaktywności w polityce zaproponowano mu stanowisko prezydenta Portugalii, odmówił jednak ze względów zdrowotnych [29], być może jednak nie tylko z tego powodu - przyjániąc się z poprzednim portugalskim prezydentem, Antonio Carmoną (18691951), bardzo nie lubił faktycznego dyktatora Portugalii Antonio Oliveiry Salazara (1889-1970).

\section{Działalność literacka}

Moniz pozostawił po sobie poważną spuściznę literacką, głównie, acz nie wyłącznie z pogranicza historii i medycyny, pisywał również krytyki literackie. Na uwagę zasługuje jego biografia papieża Jana XXI (Petrus Hispanus) (1276-1277), wykładowcy medycyny na uniwersytecie w Sienie, jedynego chyba lekarza, który został papieżem. Moniz opracował ponadto biografię jednego z pionierów hipnozy w Europie, O. Jose Custodio de Farii, urodzonego w Indiach portugalskiego mnicha, również rewolucjonisty francuskiego i więźnia Chateau d'If koło Marsylii, upamiętnionego w powieści Alexandre Dumasa Hrabia Monte Christo [30].

\section{Moniz w życiu prywatnym}

Moniz był żonaty z Elvirą de Macedo Dias (1902). Nie mieli dzieci. Prywatnie był podobno ciepłym i niezwykle sympatycznym człowiekiem, bibliofilem oraz erudytą w zakresie humanistyki, do czasu postrzelenia i niedowładu - również świetnym tancerzem, czasem komponował. Był dużej klasy graczem w karty i znawcą tego tematu. Przynajmniej raz w tygodniu spotykał się na partii kart w elitarnym gronie polityków, pisarzy i naukowców swoich czasów. W 1942 r. wydał książkę Historia kart do gry, wznowioną w 1998 r., bogato ilustrowaną rycinami starych kart [31].

\section{Dziedzictwo}

Ze zrozumiałych powodów postać Moniza jest niezwykle honorowana w Portugalii. W końcu, oprócz José 
Saramago, laureata literackiej Nagrody Nobla w 1995 r., jest jednym z dwóch portugalskich noblistów. W 1957 r. ośrodek badań Moniza został przeniesiony do Szpitala Świętej Marii w Lizbonie i zintegrowany z Wydziałem Lekarskim Uniwersytetu w Lizbonie. Dziś jest zamieniony w muzeum. Przed budynkiem stoi jego pomnik. Imieniem Moniza nazwano szpital uniwersytecki w Lizbonie, jak również sąsiadującą ulicę. Dawny wiejski dom Moniza w Avançy został przekształcony w muzeum, w którym można zobaczyć jego kolekcje dzieł sztuki (http://museuegasmoniz.cm-estarreja.pt).

\section{Podsumowanie}

Egas Moniz do dziś pozostaje postacią kontrowersyjną. Dla niektórych jest postacią czcigodną i ojcem psychochirurgii [32]. Jako wynalazca angiografii cieszy się dużym poważaniem wśród radiologów [33], a niektóre jego biogramy mają charakter wręcz hagiograficzny [2], zwłaszcza w ojczystej Portugalii [34].

Nie brakuje oczywiście głosów krytycznych. Istnieją opinie sugerujące, że ojcem psychochirurgii powinien być obwołany wspomniany wyżej Szwajcar Gottlieb Burckhardt. Sądzi się - nie bez racji - że Moniz miał więcej niż on szczęścia w popularyzacji metody i, ujmując w kategoriach współczesnych, lepszy PR [14,35].

Są to jednak sprawy poboczne wobec głównego problemu biografów Moniza, którym pozostaje jego czarna legenda. Zwłaszcza w USA jego postać jest symbolem niesławy w nauce, a na wielu stronach internetowych opisuje się jego dorobek całkowicie niezgodny z prawdac historyczną. Niekiedy np. utrzymuje się, że wszyscy chorzy z wyjściowej serii angiogramów zmarli na skutek niefrasobliwości doboru środka kontrastowego przez Moniza (nieprawda), że to Moniz wynalazł leukotom (również nieprawda), rozpowszechnia się teorie o jego rozdętym ego i chorobliwej ambicji uzyskania Nagrody Nobla etc., etc.

Prawda jest prawdopodobnie prostsza. Rzeczywiście, Egas Moniz miał pecha, opracowując metodę, która odlegle okazała się ślepym zaułkiem psychiatrii, $\mathrm{z}$ tragicznymi niekiedy następstwami. Prawdą jest również, że protokoły badawcze Moniza, zarówno z okresu wynalezienia angiografii mózgowej, jak i wdrożenia lobotomii nie wytrzymałyby dziś nawet najbardziej pobieżnej oceny jakiejkolwiek komisji oceny etycznej badań medycznych [8]. Są to jednak sądy oderwane od kontekstu historycznego. Trzeba odbyć podróż w czasie i wyobrazić sobie ówczesne szpitale psychiatryczne, zatłoczone przez setki chorych masowo umierających na choroby somatyczne, zwłaszcza gruźlicę, i ich bezradnych lekarzy, poszukujących jakiejkolwiek formy ulżenia ich losowi. Pech Moniza polegał na tym, że lobotomia została zastosowana przez ludzi, którzy nadużywając tej metody, rzeczywiście spowodowali tysiące indywidualnych tragedii. Postać Waltera Freemana rysuje się cieniem w historii amerykańskiej medycyny, również tych lekarzy w innych krajach, którzy zbyt pochopnie uwierzyli jego rzekomemu sukcesowi.

Moniz pozostaje niezwykle ważną postacią w historii radiologii. Bez kontrastowego obrazowania naczyń trudno wyobrazić sobie jej współczesność. Moniz dał początek samodzielnej specjalności owocującej dziś radiologią interwencyjną, angiografią tomografii komputerowej, perfuzyjnymi modyfikacjami jądrowego rezonansu magnetycznego i innych. To jego wielka zasługa. Natomiast jego rola w dziejach psychiatrii pozostanie przedmiotem dyskusji na długie lata [6].

Last, but not least, biografom Moniza trudno jest nie ulec zaciekawieniu jego osobowością. Był on człowiekiem renesansu przeniesionym w XX w. Lekarz neurolog, polityk, dyplomata, literat i krytyk literacki, poeta i kompozytor, hazardzista. Prawdopodobnie jego postać zasługuje na rzetelną retrospektywną analizę psychologiczną.

Po drugie, fascynuje analiza dat jego dorobku. Zakłada się, że w naukach ścisłych i przyrodniczych badacze rzadko dokonują istotnych odkryć po 40. roku życia. Osoba Moniza przeczy temu założeniu. Przypomnijmy, wynalazku angiografii dokonał w wieku 53 lat, wynalazku lobotomii w wieku 61 lat.

Postać Moniza wymyka się biało-czarnym ocenom i zasługuje na uczciwą reewaluację, w oderwaniu od przeważającego potępienia, zwłaszcza w USA, a głosami hagiograficznymi. Jego osoba zdecydowanie na taka reewaluację zasługuje, a wnioski z tej oceny mogą mieć istotny wpływ na postrzeganie historii neurologii, psychiatrii i radiologii.

\section{Podziękowania}

Emilia Sitek w trakcie przygotowywania publikacji otrzymywała stypendium START Fundacji na Rzecz Nauki Polskiej.

\section{Oświadczenie}

Autorzy zgłaszają brak konfliktu interesów. 


\section{Piśmiennictwo}

1. Schlich T. Nobel Prizes for surgeons: in recognition of the surgical healing strategy. Int J Surg 2007; 5: 129-133.

2. Tondreau R.L. Egas Moniz 1874-1955. Radiographics 1985; 5: 994-997.

3. Kevles B.H. Naked to the bone. Medical imaging in twentieth century. $3^{\text {rd }}$ ed. Rutgers University Press. New Brunswick, New Jersey 1997, ss. 105-106.

4. Moniz E. L'encephalographie arterielle, son importance dans la localisation des tumeurs cerebrales (Arterial encephalography: importance in the localization of cerebral tumours). Ann Neurol (Paris) 1927; 2: 72-90.

5. Wolpert S.M. Neuroradiology classics. AJNR Am J Neuroradiol 1999; 20: 1752-1753.

6. Heller A.C., Amar A.P., Liu C.Y. i wsp. Surgery of the mind and mood: a mosaic of issues in time and evolution. Neurosurgery 2006; 59: 720-739.

7. Mashour G., Walker E.E., Martuza R.L. Psychosurgery: past, present, and future. Brain Res Rev 2005; 48: 409-419.

8. Wind J.J. Anderson D.E. From prefrontal leukotomy to deep brain stimulation: the historical transformation of psychosurgery and the emergence of neuroethics. Neurosurgical Focus 2008; 25: E10.

9. Ogren K., Sandlund M. Psychosurgery in Sweden 1944-1964. J Hist Neurosci 2005; 14: 353-367.

10. Norbert Wiener. Cybernetics. MIT Press, USA 1948, s. 148.

11. Приказ МЗ СССР 1003 (9 дек. 1950). Невропатология и психиатрия 1951; 20: 17-18.

12. Licherman B.L. On the history of psychosurgery in Russia. Acta Neurochir (Wien) 1993; 125: 1-4.

13. Masiero A.L. Lobotomy and leucotomy in Brazilian mental hospitals. Hist Cienc Saude Manguinhos 2003; 10: 549-572.

14. Gross D., Schäfer G. Egas Moniz (1874-1955) and the "invention" of modern psychosurgery: a historical and ethical reanalysis under special consideration of Portuguese original sources. Neurosurg Focus 2011; 30: E8.

15. Kotowicz Z. Gottlieb Burckhardt and Egas Moniz - two beginnings of psychosurgery. Gesnerus 2005; 62: 77-101.

16. Moniz E. Essai d'un traitement chirurgical de certaines psychoses. Bulletin de l'Académie de Médecine 1936; 115: 385-392.

17. Shorter E. A history of psychiatry. Wiley 1997, ss. 190-225.

18. Rowland L.P. Walter Freeman's psychosurgery and biological psychiatry: a cautionary tale. Neurology Today 2005; 5: 70-72.

19. Freeman W., Watts J.W. Psychosurgery. Intelligence, emotion and social behavior following prefrontal lobotomy for mental disorders. Charles C Thomas Publisher, Springfield 1942.

20. Moniz E. Prof. Egas Moniz defends prefrontal lobotomy in a communication to the Lisbon Academy of Sciences. J Med (Oporto) 1954; 17: 677-679.

21. Feldman B. The Nobel Prize: a history of genius, controversy, and prestige. Arcade Publishing, New York 2001.

22. Ligon B.L. The mystery of angiography and the "unawarded" Nobel Prize: Egas Moniz and Hans Christian Jacobaeus. Neurosurgery 1998; 43: 602-611.

23. Correia M. Egas Moniz: Representaçao, saber e poder (Egas Moniz: reprezentacja, wiedza i władza). Rozprawa doktorska. Wydziat Historii Uniwersytetu w Coimbra, Coimbra 2010.
24. Stolt, C.M. Moniz, lobotomy and the Nobel Prize 1949. Sven Med Tiskr 1999; 3: 249-270.

25. Ferro J.M. Egas Moniz and internal carotid occlusion. Arch Neurol 1988; 45: 563-584.

26. Moniz E. Diagnostic des tumeurs cérébrales et épreuve de l'encéphalographie artérielle (Diagnostics of cerebral tumours and application of arterial encephalography). Masson, Paris 1931.

27. Moniz E. A Vida Sexual (Fisiologia e Patologia), Junçåo dos dois volumes anteriores, consideravelmente alterados em alguns capitulos. Coimbra, 1901.

28. Gorelick P.B., Biller J. Egas Moniz: neurologist, statesman, and Nobel laureate. J Lab Clin Med 1991; 118: 1200-1202.

29. Moniz E.A. Obituary. Br Med J 1955; 4955: 1565-1570.

30. Moniz E. O Padre Faria na história do Hipnotismo Lisboa: Faculdade de Medicina de Lisboa, 1925.

31. Moniz E. Historia das cartas de jogar. Apenas Livros $L d a$, Lizbona 1998.

32. Fusar-Poll P., Alen P., McGuire P. Egas Moniz (1875-1955), the father of psychosurgery. BrJ Psychiatr 2008; 193: 50.

33. Doby T. Cerebral angiography and Egas Moniz. AJR Am J Roentgenol 1992; 159: 364.

34. Tavares A. Egas Moniz, a scholar with the soul of a poet. J Med (Oporto) 1966; 22: 199-201.

35. Manjila S., Rengachary S., Xavier A.R. i wsp. Modern psychosurgery before Egas Moniz: a tribute to Gottlieb Burckhardt. Neurosurg Focus 2008; 25: E9. 